\title{
Real-Time Remote Tele-Mentored Echocardiography: A Systematic Review
}

\author{
Alexis Salerno ${ }^{1}$, Diane Kuhn ${ }^{1}$, Rayan El Sibai ${ }^{1}$, Andrea R. Levine ${ }^{2}$ and Michael T. McCurdy ${ }^{1,2, *}$ \\ 1 Department of Emergency Medicine, University of Maryland School of Medicine, \\ Baltimore, MD 21201, USA; alexis.salerno@som.umaryland.edu (A.S.); dmkuhn08@gmail.com (D.K.); \\ rayan.sibai@som.umaryland.edu (R.E.S.) \\ 2 Division of Pulmonary and Critical Care Medicine, University of Maryland School of Medicine, \\ Baltimore, MD 21201, USA; andrea.levine@som.umaryland.edu \\ * Correspondence: drmccurdy@gmail.com
}

Received: 29 October 2020; Accepted: 30 November 2020; Published: 2 December 2020

\begin{abstract}
Background and Objectives: Real-time remote tele-mentored echocardiography (RTMUS echo) involves the transmission of clinical ultrasound (CU) cardiac images with direct feedback from a CU expert at a different location. In this review, we summarize the current uses of RTMUS to diagnose and manage cardiovascular dysfunction and discuss expanded and future uses. Materials and Methods: We performed a literature search (PubMed and EMBase) to access articles related to RTMUS echo. We reviewed articles for selection using Covidence, a web-based tool for managing systematic reviews and data were extracted using a separate standardized collection form. Results: Our search yielded 15 articles. Twelve of these articles demonstrated the feasibility of having a novice sonographer mentored by a tele-expert in obtaining a variety of cardiac ultrasound views. The articles discussed different technological specifications for the RTMUS system, but all showed that adequate images were able to be obtained. Overall, RTMUS echo was found to be a positive intervention that contributed to patient care. Conclusion: RTMUS echo allows for rapid access to diagnostic imaging in various clinical settings. RTMUS echo can help in assessing patients that may require a higher level of isolation precautions or in other resource-constrained environments. In the future, identifying the least expensive way to utilize RTMUS echo will be important.
\end{abstract}

Keywords: teleultrasound; clinical ultrasound; echocardiography; critical care; SARS-CoV-2

\section{Introduction}

A significant portion of hospitalized patients present with hemodynamic instability [1]. Assessing cardiovascular function is essential to properly manage these patients, and the information garnered from clinical ultrasound (CU) echocardiography routinely alters clinical decisions [2,3]. Unfortunately, in many resource-constrained environments, individuals trained in CU echocardiography may not be immediately available or personnel may be restricted due to a high level of isolation precautions, such as for patients infected with SARS-CoV-2 [4,5].

The use of real-time, remote tele-mentored echocardiography, also termed remote tele-mentored ultrasound echocardiography (RTMUS echo), can provide a useful tool in environments that are resource-constrained or subject to strict isolation precautions by utilizing off-site experts to enhance the clinical information obtained at bedside. RTMUS echo can be used to evaluate left and right ventricular function, valvular function, and to aid in the diagnosis of pathologies such as tamponade. One common way to implement RTMUS echo is through the use of an ultrasound expert at a remote location who provides real-time guidance to novice ultrasound personnel in order to obtain cardiac ultrasound images that can be interpreted to direct further clinical care [6]. 
Although research on the use of RTMUS echo has been increasing in recent years, there is limited literature discussing how and by whom RTMUS echo is being used. We conducted a systematic review with the objective of summarizing the current uses of RTMUS echo to diagnose and manage cardiovascular dysfunction, and based on our findings, to discuss futures uses.

\section{Materials and Methods}

For this review, we searched the PubMed and EMbase databases for all relevant studies published before 22 July 2020. Please see Appendix A for specific search terms.

Studies were deemed relevant to our systematic review if they met the following criteria: (1) describe RTMUS echo in patients 18 years and older, (2) do not involve the use of augmented reality or robotics, and (3) are written in English.

The characteristics and results of the selected studies were reviewed, and data were extracted using Covidence, a web-based tool for managing systematic reviews. The data were then recorded in a separate standardized data collection form. The citations were reviewed for relevancy by two members of the study team; if they disagreed, they discussed the articles until reaching a consensus. From the studies that met our selection criteria, we extracted the following data: year published, journal title, authors, article title, study design, objective of study, study setting, number of learners, level of training of the learners, cardiac views performed, technology used, and study results.

\section{Results}

\subsection{Studies Selected}

We identified a total of 753 articles, posters, abstracts, and reviews satisfying the search terms. We excluded 106 duplicate results and 475 irrelevant articles. On closer examination, we excluded 157 studies which did not meet the study criteria. This left 15 studies for inclusion in our review. The flow diagram illustrates the selection process for our review (Figure 1).

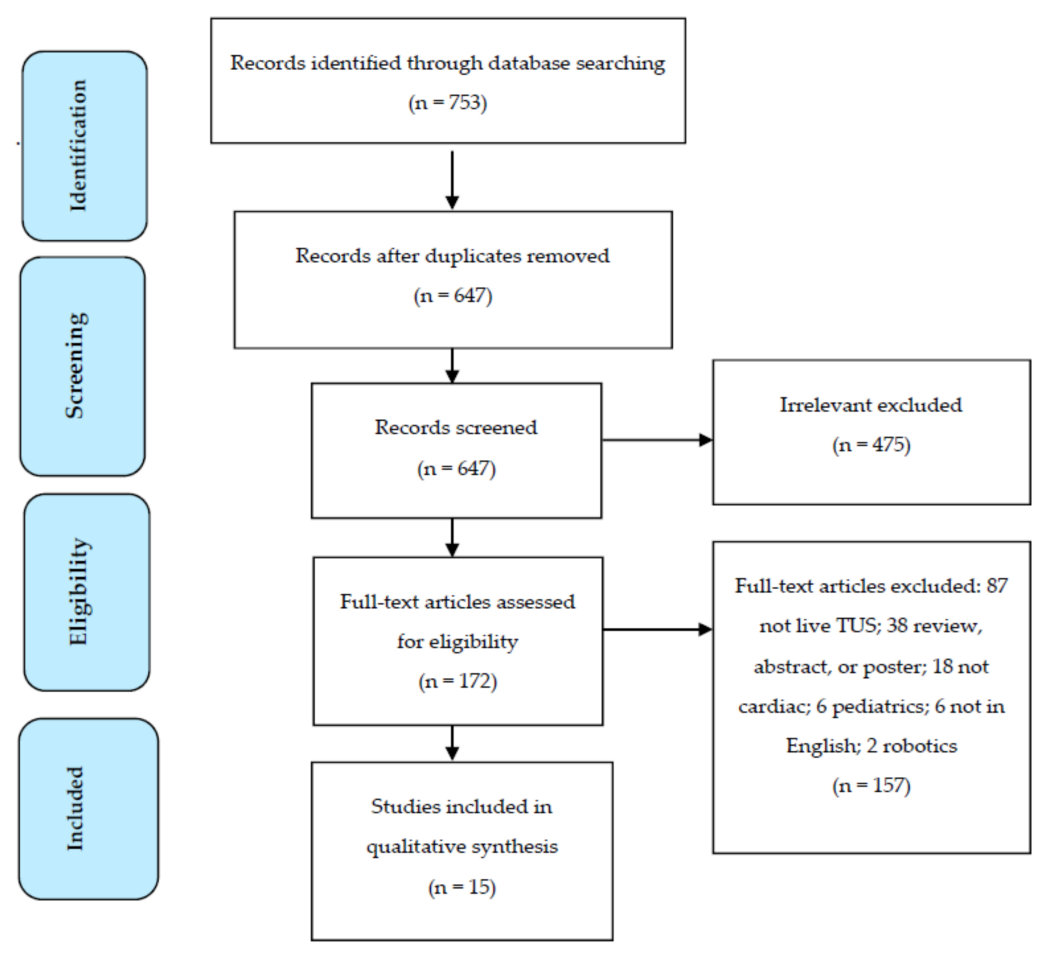

Figure 1. Prisma Flowsheet for Study Selection [7]. 


\subsection{Characteristics of Studies}

The characteristics of the included studies are summarized in Table 1. The studies ranged widely in terms of questions posed and the specific use of RTMUS echo. The tele-mentors were intensivists, anesthesiologists, emergency physicians, or cardiologists. Twelve of the 15 studies included tele-mentoring of an inexperienced sonographer [8-19]. These sonographers included physicians, paramedics, nurses, and non-medically trained individuals who were able to obtain a variety of cardiac ultrasound views.

RTMUS echo was used to evaluate cardiac function and pathology, such as cardiac tamponade or RV strain [12,15]. Four of the articles discussed the use of advanced cardiac evaluations using RTMUS echo, such as E-point septal separation (EPSS) to approximate ejection fraction (EF) [9,13,19], M-mode and Doppler flow measurements to evaluate valvular pathology [13], and inferior vena cava (IVC) respiratory variation to assess signs of fluid responsiveness [14].

Substantial heterogeneity across studies existed among both the types of experts and learners and the outcomes of interest. The varying outcomes included time to image acquisition [11,20], ability to make clinical decisions based on obtained images [10], and degree of correlation of RTMUS echo images findings to other imaging studies or in-person expert sonographer assessments [12,13].

The role of technology in RTMUS echo emerged as a recurrent theme highlighted in the reviewed articles. Several different ultrasound machines and communication methods were used among the studies. Please see Table 2 for further details. 
Table 1. RTMUS Echo Study Features.

\begin{tabular}{|c|c|c|c|c|c|c|c|}
\hline Article & Study Design and Setting & Objective & $\begin{array}{c}\text { Number and } \\
\text { Experience Level of } \\
\text { Learners/Sonographers }\end{array}$ & $\begin{array}{l}\text { Number of Patients and } \\
\text { Patient Population }\end{array}$ & $\begin{array}{l}\text { Cardiac US Views and } \\
\text { Measurements Obtained }\end{array}$ & Outcome Measures & Results \\
\hline $\begin{array}{l}\text { Afset et al. } \\
\text { (1996) [13] }\end{array}$ & $\begin{array}{l}\text { Feasibility study, } \\
\text { community hospital, } \\
\text { Norway }\end{array}$ & $\begin{array}{l}\text { Evaluate reproducibility and } \\
\text { accuracy of RTMUS } \\
\text { echo measurements }\end{array}$ & One novice physician & $\begin{array}{l}38 \text { patients with known or } \\
\text { suspected heart disease }\end{array}$ & $\begin{array}{l}\text { PSL, A4C; EPSS, Doppler } \\
\text { to estimate MR, AR, } \\
\text { TR/pulmonic flow }\end{array}$ & $\begin{array}{l}\text { Learner's measurements compared } \\
\text { to expert US examination }\end{array}$ & $\begin{array}{l}\text { No difference between expert and } \\
\text { RTMUS assessments of mean } \\
\text { M-mode or Doppler variables }\end{array}$ \\
\hline $\begin{array}{l}\text { Miyashita et al. } \\
\text { (2003) [20] }\end{array}$ & $\begin{array}{l}\text { Feasibility study, mobile } \\
\text { health vehicle, Japan }\end{array}$ & $\begin{array}{l}\text { Evaluate ability to effectively } \\
\text { transmit US images via satellite }\end{array}$ & Echocardiography specialist & 57 patients & Not specified & $\begin{array}{l}\text { Image quality and acquisition time } \\
\text { compared to US machine images }\end{array}$ & $\begin{array}{l}\text { Average exam time } 8.4 \mathrm{~min} \\
\text { (range, 6.1-10.1). Quality nearly } \\
\text { identical to original }\end{array}$ \\
\hline $\begin{array}{l}\text { Huffer et al. } \\
(2004)[21]\end{array}$ & $\begin{array}{l}\text { Feasibility study, simulated } \\
\text { mass casualty, USA }\end{array}$ & $\begin{array}{l}\text { Determine feasibility and } \\
\text { diagnostic accuracy of RTMUS } \\
\text { during mass casualty }\end{array}$ & Trained sonographers & $\begin{array}{l}10 \text { individuals with known } \\
\text { structural cardiac disease } \\
\text { and } 2 \text { healthy controls }\end{array}$ & $\begin{array}{l}\text { LVEF, RV Strain, RWM, LV } \\
\text { size, AV/MV pathology }\end{array}$ & $\begin{array}{l}\text { Technical quality and } \\
\text { diagnostic accuracy }\end{array}$ & $\begin{array}{l}\text { Overall average of 95\% concordance } \\
\text { between two sets of images }\end{array}$ \\
\hline $\begin{array}{l}\text { Boniface et al. } \\
\text { (2011) [8] }\end{array}$ & $\begin{array}{l}\text { Feasibility study, simulated } \\
\text { pre-hospital setting, USA }\end{array}$ & $\begin{array}{l}\text { Assess ability of paramedics to } \\
\text { obtain adequate views } \\
\text { using RTMUS }\end{array}$ & 51 novice paramedics & Healthy volunteer & $\begin{array}{l}\text { Subx; PSL if inadequate } \\
\text { subx }\end{array}$ & Adequacy of views (yes/no) & $\begin{array}{l}\text { Success rate of } 100 \% \text { to obtain } \\
\text { "adequate" views }\end{array}$ \\
\hline $\begin{array}{l}\text { Otto et al. } \\
\text { (2012) [15] }\end{array}$ & $\begin{array}{l}\text { Case report, community } \\
\text { hospital, Antarctica }\end{array}$ & $\begin{array}{l}\text { Demonstrate ability of RTMUS } \\
\text { to serve as important diagnostic } \\
\text { tool in remote environments }\end{array}$ & $\begin{array}{l}\text { One physician with "basic" } \\
\text { CU skills }\end{array}$ & One patient & Subx, PSL, PSS, A4C & No formal analysis & $\begin{array}{c}\text { Diagnosis of pericarditis; RTMUS } \\
\text { prevented unnecessary } \\
\text { transcontinental medical evacuation }\end{array}$ \\
\hline $\begin{array}{l}\text { Russell et al. } \\
\text { (2014) [9] }\end{array}$ & $\begin{array}{l}\text { Prospective, randomized, } \\
\text { single-blinded, academic } \\
\text { setting, USA }\end{array}$ & $\begin{array}{l}\text { Compare ability to obtain PSLA } \\
\text { US views for (1) no, (2) remote, } \\
\text { and (3) in-person mentoring }\end{array}$ & 18 novice medical students & $75 \mathrm{~kg}$ live model & PSL; EPSS & Adequacy and quality of EPSS & No significant difference \\
\hline $\begin{array}{l}\text { Levine et al. } \\
\text { (2016) [18] }\end{array}$ & $\begin{array}{c}\text { Feasibility study, academic } \\
\text { setting, USA }\end{array}$ & $\begin{array}{l}\text { Determine ability of } \\
\text { telemedicine ICU physicians to } \\
\text { mentor remote sonographers to } \\
\text { obtain US images }\end{array}$ & $\begin{array}{l}11 \text { novice non-physician health } \\
\text { care providers }\end{array}$ & One healthy volunteer & Subx & $\begin{array}{l}\text { Compare image quality and ability to } \\
\text { make clinical decisions from US } \\
\text { machine or RTMUS }\end{array}$ & $\begin{array}{l}\text { Of RTMUS images, } 69 / 77(90 \%) \text { were } \\
\text { high quality and } 74 / 77(96 \%) \\
\text { permitted clinical decision making }\end{array}$ \\
\hline $\begin{array}{l}\text { Becker et al. } \\
(2017)[14]\end{array}$ & $\begin{array}{l}\text { Case report, tertiary } \\
\text { hospital ICU, USA }\end{array}$ & Evaluate fluid responsiveness & One provider with $\mathrm{CU}$ training & One patient & PSL, A4C, IVC & $\begin{array}{l}\text { RTMUS exam showed signs of } \\
\text { distributive and hypovolemic shock }\end{array}$ & $\begin{array}{l}\text { Patient given fluid with increase in } \\
\text { MAP and vasopressors stopped }\end{array}$ \\
\hline $\begin{array}{l}\text { Kim et al. } \\
\text { (2017) [19] }\end{array}$ & $\begin{array}{l}\text { Feasibility study, tertiary } \\
\text { hospital ICU, Korea }\end{array}$ & $\begin{array}{l}\text { Determine ability of remote } \\
\text { expert to evaluate EF with } \\
\text { RTMUS using social network } \\
\text { video call }\end{array}$ & 60 novice sonographers & 60 patients & PSL, PSS, A4C; EPSS, EF & $\begin{array}{l}\text { Compare cardiologist-performed } \\
\text { Simpson's method vs. RTMUS EF } \\
\text { and EPSS evaluation }\end{array}$ & $\begin{array}{l}\text { Statistically excellent agreement } \\
\text { between two measurements of EF }\end{array}$ \\
\hline $\begin{array}{l}\text { Robertson et al. } \\
\text { (2017) [10] }\end{array}$ & $\begin{array}{l}\text { Feasibility study, } \\
\text { community hospital, Haiti }\end{array}$ & $\begin{array}{l}\text { Determine ability of remote } \\
\text { tele-intensivist to mentor } \\
\text { providers to obtain US images }\end{array}$ & $\begin{array}{l}9 \text { novice non-physician } \\
\text { healthcare workers }\end{array}$ & One healthy volunteer & Subx & $\begin{array}{l}\text { Comfort of making clinical decisions } \\
\text { based on images, image quality }\end{array}$ & $\begin{array}{l}\text { Tele-intensivist could make clinical } \\
\text { decisions with } 56 / 63(89 \%) \text { images, of } \\
\text { which } 57 / 63(90 \%) \text { were high quality }\end{array}$ \\
\hline $\begin{array}{l}\text { Epstein et al. } \\
\text { (2018) [16] }\end{array}$ & Rural hospital, Uganda & $\begin{array}{l}\text { Evaluate ability of physician to } \\
\text { detect major US findings after } \\
\text { basic training }\end{array}$ & $\begin{array}{l}\text { One physician underwent } \\
\text { 5-day training }\end{array}$ & $\begin{array}{l}7 \text { echo studies, not specified } \\
\text { \# of real-time }\end{array}$ & Not specified & $\begin{array}{l}\text { Assess image utility to make } \\
\text { clinical decisions }\end{array}$ & $\begin{array}{l}\text { RTMUS via smartphone for echo } \\
\text { image feasible, reducing need for } \\
\text { complete echo studies }\end{array}$ \\
\hline $\begin{array}{l}\text { Douglas et al. } \\
\text { (2019) [17] }\end{array}$ & $\begin{array}{l}\text { Feasibility study, pilot } \\
\text { cohort and clinical cohort, } \\
\text { community ICU, USA }\end{array}$ & $\begin{array}{l}\text { Assess US training (1) effect on } \\
\text { non-physician comfort } \\
\text { performing TUS and (2) } \\
\text { feasibility to improve } \\
\text { participant comfort }\end{array}$ & $\begin{array}{l}\text { Pilot cohort: } 11 \text { non-physician } \\
\text { providersClinical cohort: } \\
5 \text { ICU nurses }\end{array}$ & $\begin{array}{l}\text { Pilot cohort: } 1 \text { healthy } \\
\text { volunteerClinical cohort: } \\
\text { ICU inpatients over } 6 \text { weeks }\end{array}$ & $\begin{array}{l}\text { Pilot cohort: SubxClinical } \\
\text { cohort: PSL, PSS, Subx }\end{array}$ & $\begin{array}{l}\text { Participant survey of experience and } \\
\text { comfort of performing RTMUS }\end{array}$ & $\begin{array}{l}\text { After training, all participants had } \\
\text { positive experience and comfortable } \\
\text { using RTMUS }\end{array}$ \\
\hline $\begin{array}{l}\text { Jensen et al. } \\
\text { (2019) [22] }\end{array}$ & $\begin{array}{l}\text { Single-blinded cluster } \\
\text { randomized control trial, } \\
\text { regional ED, Denmark }\end{array}$ & $\begin{array}{l}\text { Investigate image quality of } \\
\text { cine-loop recordings of RTMUS } \\
\text { vs. non-supervised physician's } \\
\text { vs. experts }\end{array}$ & $\begin{array}{l}10 \text { physicians with prior } \\
\text { CU training }\end{array}$ & 44 patients & Subx, PSL, PSS, A4C & $\begin{array}{l}\text { Two blinded observers graded } \\
\text { cine-loops recorded from all scans }\end{array}$ & $\begin{array}{l}\text { RTMUS images had higher image } \\
\text { quality than those by } \\
\text { unsupervised physicians }\end{array}$ \\
\hline $\begin{array}{l}\text { Ramsingh et al. } \\
\text { (2019) [11] }\end{array}$ & $\begin{array}{l}\text { Feasibility study, academic } \\
\text { setting, USA }\end{array}$ & $\begin{array}{l}\text { Assess anestheriologist ability } \\
\text { to guide remote nonmedical } \\
\text { learners to obtain US images }\end{array}$ & $\begin{array}{l}21 \text { novice non-medically } \\
\text { trained students }\end{array}$ & One healthy volunteer & PSL, PSS & $\begin{array}{l}\text { Image acquisition time, } \\
\text { Quality of Image }\end{array}$ & $\begin{array}{c}\text { Average exam time } 8.5 \mathrm{~min}, 90 \% \\
\text { cardiac images had } \geq 3 \text { out of } \\
4 \text { quality rating }\end{array}$ \\
\hline $\begin{array}{l}\text { Olivieri et al. } \\
\text { (2020) [12] }\end{array}$ & $\begin{array}{l}\text { Feasibility study, } \\
\text { community ICU, USA }\end{array}$ & $\begin{array}{l}\text { Evaluate ability of RTMUS to } \\
\text { approximate CU exam } \\
\text { performed by provider }\end{array}$ & 5 novice ICU nurses & 20 patients & PSL, PSS, Subxiphoid & $\begin{array}{l}\text { Concordance between RTMUS and } \\
\text { CU and clinical test }\end{array}$ & High specificity for all abnormalities \\
\hline
\end{tabular}

$\mathrm{AR}$, aortic regurgitation; $\mathrm{TR}$, tricuspid regurgitation; $\mathrm{US}$, ultrasound; $\mathrm{LV}$, left ventricle; $\mathrm{PE}$, pulmonary embolism; $\mathrm{RWM}$, regional wall motion abnormality; $\mathrm{AV}$, aortic valve; $\mathrm{MV}$, mitral valve; EP, emergency physician; Subx, subxiphoid view; CU, clinical ultrasound; PSS, parasternal short axis view; MAP, mean arterial pressure; EF, ejection fraction; ED, Emergency Department. 
Table 2. RTMUS Echo Study Features.

\begin{tabular}{|c|c|c|c|c|}
\hline Article Title & US Machine & Recording and Transmission Technology & Capture, Resolution, and Data Transfer Rate & Delay, Distortions, and Cost \\
\hline Afset et al. (1996) [13] & 270 SSA (Toshiba) & $\begin{array}{l}\text { Videoconference signals digitized by computer before } \\
\text { transmission through digital telecommunication } \\
\text { channels using a system called MEGA-NET }\end{array}$ & $\begin{array}{l}\text { Video codec (Philips VCD 2M-G) compressed } \\
\text { video signals by } 97 \% \text {. MEGA-NET } \\
\text { capacity of } 2 \text { Mbps. }\end{array}$ & $\begin{array}{c}\text { Cost of equipment } \sim \text { USD } 34,500 \text { per } \\
\text { site. Cost of video conference } \\
\sim(\text { USD 28/h) }\end{array}$ \\
\hline Miyashita et al. (2003) [20] & Dyna View-II SSD 1700 (Aloka) & $\begin{array}{l}\text { Remote-controlled camera at exam site, images } \\
\text { transmitted using satellite links (JCSAT-1B) as } \\
\text { videoconferencing and DICOM images }\end{array}$ & $\begin{array}{l}\text { Meeting system could transmit images of } \\
640 \times 480 \text { pixels at an upload rate } \\
\text { of } 30 \text { fps at best. }\end{array}$ & $\begin{array}{l}\text { RTMUS system cost USD } 30,000 \text { and } \\
\text { the communication cost } ~ \\
\text { USD } 4 \text { per min. }\end{array}$ \\
\hline Huffer et al. (2004) [21] & VISICU, Inc. & MPEG-2 compression technology & $\begin{array}{l}\text { Capture rate of } 32 \mathrm{fps} \text {, needed higher } \\
\text { gain than usual. }\end{array}$ & \\
\hline Boniface et al. (2011) [8] & $\begin{array}{l}\text { Sonosite Micromaxx, } \\
\text { M-Turbo (Fujifilm) }\end{array}$ & $\begin{array}{l}\text { Physician communicating with paramedic via } \\
\text { two-way radio }\end{array}$ & & \\
\hline Otto et al. (2012) [15] & $\begin{array}{l}\text { Acuson US and } \\
\text { TeleRad workstation }\end{array}$ & $\begin{array}{l}\text { Transmitted via McMurdo Station's T-1 satellite } \\
\text { communications link }\end{array}$ & $\begin{array}{l}\text { Data link of } 384 \text { Kbps to } \\
\text { McMurdo Station's LAN }\end{array}$ & \\
\hline Russell et al. (2014) [9] & Vscan(GE Healthcare) & Mentoring via Google Glass and Google Hangouts & & Google Glass estimated at USD 1500 \\
\hline Levine et al. (2016) [18] & SonoSite S-ICU (Fujifilm) & Tele-ICU camera: images captured using Sony camera & $\begin{array}{c}\text { Camera had } 340^{\circ} \text { pan, } 120^{\circ} \text { tilt, } 18 \times \text { optical, } \\
12 \times \text { digital, and } 380 \mathrm{k} \text { pixels }\end{array}$ & \\
\hline Becker et al. (2017) [14] & Not provided & No information provided & No information provided & No information provided \\
\hline Kim et al. (2017) [19] & Logiq S8 (GE Healthcare) & $\begin{array}{l}\text { Video call (Kakao face talk) with 4G network using a } \\
\text { Galaxy S7 (Samsung) }\end{array}$ & US machine with $1920 \times 1080$-pixel LED & \\
\hline Robertson et al. (2017) [10] & SonoSite M-Turbo (FujiFilm) & $\begin{array}{c}\text { Apple MacBook laptop, connected to sonographer in } \\
\text { Haiti via an Apple iPhone } 5 S \text {, both operating Apple's } \\
\text { FaceTime app }\end{array}$ & $\begin{array}{l}\text { Apple iPhone running FaceTime using } 4 \mathrm{G} \\
\text { cellular data network }\end{array}$ & \\
\hline Epstein et al. (2018) [16] & Vscan (GE Healthcare) & $\begin{array}{l}\text { Cellular phones, commercially available video-chat } \\
\text { software, and } 3 G \text { cellular data network }\end{array}$ & & \\
\hline Douglas et al. (2019) [17] & SonoSite X-Porte (Fujifilm) & $\begin{array}{l}\text { Two-way camera to visualize both US machine and } \\
\text { sonographer; remote tele-intensivist used Philips } \\
\text { monitoring software }\end{array}$ & & \\
\hline Jensen et al. (2019) [22] & Vivid S6 (GE Healthcare) & $\begin{array}{l}\text { Video grabber (DVI2USB 3.0; Epiphan Video), } \\
\text { two web cameras, headset, two laptop computers } \\
\text { (on-site and remote) }\end{array}$ & & \\
\hline Ramsingh et al. (2019) [11] & SonoSite Edge (Fujifilm) & $\begin{array}{l}\text { Apple FaceTime and Google Glass, with one-way } \\
\text { visual communication and two-way } \\
\text { audio communication }\end{array}$ & & \\
\hline Olivieri et al. (2020) [12] & SonoSite X-Porte (Fujifilm) & $\begin{array}{l}\text { Philips audiovisual communication link, Philips } \\
\text { monitoring software, and videoconference with } \\
\text { camera (Sony EVI-D70) }\end{array}$ & $\begin{array}{l}\text { Camera had } 18 x \text { lens with horizontal } \\
\text { resolution of } 470 \text { television lines (TVL) }\end{array}$ & $\begin{array}{l}\text { Facilities and equipment from } \\
\text { preexisting tele-ICU }\end{array}$ \\
\hline
\end{tabular}

second; LAN, local area network; Mbps, megabits per second; TVL, television lines. All monetary values in US dollars. 


\section{Discussion}

\subsection{An RTMUS Echo Foundation}

RTMUS can assist with diagnosing and treating patients in resource-constrained environments $[4,6,10,23]$. In this review, we specifically looked at the role of RTMUS echo, which can be a powerful tool to identify cardiovascular dysfunction. By using RTMUS echo, providers can evaluate left ventricular function, right ventricular function, and valvular pathologies in critically ill patients. RTMUS can also help to diagnosis emergent conditions such as tamponade, pulmonary embolism, and left ventricular failure.

As with any technological advancement, RTMUS echo requires a large amount of planning prior to implementation. At present, four integral parts exist in an RTMUS echo program [6]:

1. An ultrasound operator at bedside who can perform images;

2. An ultrasound;

3. A technological platform that can provide active communication between the sonographer and ultrasound expert with simultaneous transmission of ultrasound images and probe location on the patient;

4. An expert ultrasound consultant for interpretation.

\subsection{RTMUS Echo Training of Novice Users}

With little prior education, individuals with different levels of training can adequately obtain ultrasound images $[9,10,17]$. A large portion of the studies discussed a didactic session prior to initiation of RTMUS. The didactic sessions varied amongst the studies and ranged between 20 and 60 min [8,10-12,17,18]. Other studies discussed ultrasound education through RTMUS [9].

\subsection{RTMUS Technology}

Communication must exist between the sonographer and/or ultrasound machine to a remote ultrasound expert. A wide variety of ultrasound machines were used for the studies presented in this analysis, including SonoSite (Fujifilm), LOGIQ S8 (GE Healthcare), and VScan (GE Healthcare) $[11,13,16,19,20]$. With the increasing prevalence and decreasing cost of small handheld devices such as the Butterfly $\mathrm{iQ}+$, the availability of this technology in remote areas or in low- and middle-income countries is likely to become commonplace. Additionally, small handheld devices may be more feasible in high isolation patients, as they are easier to clean and decrease the risk of device contamination.

\subsection{RTMUS Interpretation of Images}

Effective transmission of high-quality images, which is essential for a functioning RTMUS echo program, was accomplished either through low-cost RTMUS transmission systems [24] or with images/video from publicly available apps such as FaceTime from a 3G or higher cell phone [18]. In general, when ultrasound videos were compressed for transmission, authors indicated that a camera capture rate of at least 30 frames per second was preferable in order to ensure adequate resolution. The authors suggested a resolution of at least $640 \times 480$ pixels [20,21].

Prior research indicates that images sent by an RTMUS echo system are noninferior to live ultrasound machine images when adequate technology is used [9,10,19-21]. For example, the interpretation of EF from images transmitted via a social network was noninferior and had excellent correlation $(0.94 ; p<0.001)$ to the EF calculated by the modified Simpson method [19]. RTMUS echo also improves image quality as compared to unsupervised images. One study indicated that non-expert images moved 9\% closer to expert quality views by using RTMUS echo [22]. 


\subsection{RTMUS Technological Considerations}

Matching the level of technological support (e.g., US machine, image transmission platform) with the clinical environment is important to ensure a cost-effective program. For example, in a pre-hospital or mass casualty setting, in which identification of active bleeding, pneumothorax, or tamponade may be the highest priority, mild distortions due to video capture rate or resolution may be clinically insignificant. Furthermore, in low-resource settings, tradeoffs between quality of image and the availability of ultrasonography may focus on using the least expensive technology able to answer the clinical question at hand.

\subsection{RTMUS Echo Use in SARS-CoV-2 and Other High Isolation Areas}

The SARS-CoV-2 pandemic has strained almost every aspect of society and particularly, health care systems. The scientific community is adapting and learning how to contend with SARS-CoV-2. Though knowledge of the effects of the pandemic on the respiratory and cardiovascular systems is still in its infancy, research and progress are exponentially increasing. Several imaging techniques are available to diagnose, understand, and clinically manage the effects of SARS-CoV-2. These techniques include chest X-ray, computed tomography $(\mathrm{CT})$ of the chest, and CU. Chest radiographic findings of pulmonary disease are usually absent early in the disease and sensitivity may be only 69\% [25,26]. CT scans offer the advantage of providing significant information such as estimation of disease severity and evaluation for pulmonary embolism [26]. The American College of Radiology advocates CT scanner decontamination after imaging any patient with suspected SARS-CoV-2, a practice that limits CT scanner availability [27]. Additionally, CT scans require patient transport throughout the hospital, increasing the possibility for infection control failures. Given the volume of SARS-CoV-2 patients, many of whom are critically ill, using CT may be unsafe and impractical. On the contrary, CU can be performed at bedside, with portable devices being left in a patient's room or within a biocontainment unit, decreasing contamination risk.

CU can be used for cardiac and pulmonary evaluation, severity stratification, and monitoring of patients with suspected SARS-CoV-2 infection. It can be used to identify left ventricular diastolic dysfunction as well as right ventricular dilatation and impairment, findings which have been described in patients with severe SARS-CoV-2 infection [28].

$\mathrm{CU}$ is an integral part of the evaluation of a critically ill patient. Most of these patients will have serial CU examinations to look for changes in their EF and to look for signs of fluid tolerance or intolerance. CU operators are in close contact with patients and therefore, at a high risk of being infected. Expert consensus supports judiciously selected imaging techniques to minimize the risk of infectious exposure of health care personnel or other patients [29]. As such, the most experienced operator may not be the ideal operator in every clinical situation. Thus, the role of RTMUS may increase among SARS-CoV-2 patients to retain expert evaluation while minimizing physical interaction with patients.

\subsection{Future Direction and Research of RTMUS Echo}

RTMUS echo is a newer technology with great potential to provide high-level expertise to low-resource settings. In the future, we will need to advance the use of RTMUS echo to become standardized in these settings.

Most of the articles we reviewed are small studies or case reports. In the future, large scale studies will help to establish the use of RTMUS echo in different clinical settings. Future studies on RTMUS echo must also revisit the tradeoffs between time and cost, on the one hand, and superior data transfer and image resolution, on the other. One step toward addressing these tradeoffs will be to determine a minimally useful image quality and the technology required to achieve this quality. Finally, although cost of technology was briefly addressed in some studies, identifying the least expensive and easiest 
ways to implement tele-ultrasound, such as with a handheld device or with asynchronous transmission, will be important.

\section{Conclusions}

In our review of the literature, 15 articles addressed the use of RTMUS echo to evaluate cardiac dysfunction. These studies highlighted the feasibility of tele-mentoring novice sonographers to obtain clinically useful images, as well as tele-mentoring for the sake of education and improving comfort with the use of ultrasonography. To decrease provider exposure to high risk areas and conserve limited personal protective equipment, RTMUS echo may have an increasing role in use among patients in high isolation clinical settings such as those needed to manage patients with COVID-19. Staying abreast of the fastest and most cost-effective ways to implement RTMUS echo to produce and transmit quality images for interpretation will help to ensure that ongoing changes in technology are appropriately being leveraged to deliver optimal patient care.

Author Contributions: Review articles for study selection, A.S., R.E.S.; extraction of data, D.K.; writing-original draft preparation, A.S., R.E.S., D.K.; writing—review and editing, A.R.L., M.T.M. All authors have read and agreed to the published version of the manuscript research articles.

Funding: This research received no external funding.

Acknowledgments: Deborah M. Stein, ELS, provided language and technical editing of the manuscript.

Conflicts of Interest: The authors declare no conflict of interest.

\section{Appendix A}

For the PubMed database, we used Medical Subject Headings (MeSH) terms within titles and abstracts (tiab):

- $\quad((($ “Telemedicine/utilization”[MeSH]) OR “Remote Consultation”[ $\mathrm{MeSH}])$ OR “Teleradiology”[MeSH] OR telemedicine[tiab])) AND ("echocardiography/utilization"[MeSH] OR echocardiography[tiab])

- $\quad(((($ “Telemedicine/utilization”[MeSH]) OR “Remote Consultation”"[MeSH]) OR “Teleradiology”[MeSH] OR telemedicine[tiab])) AND (“Ultrasonography/utilization”[MeSH] OR ultrasound[tiab])

For the EMbase database, we used the terms

- ('echocardiography'/exp AND 'telemedicine'/exp).

\section{References}

1. Cecconi, M.; De Backer, D. Consensus on circulatory shock and hemodynamic monitoring. Task force of the European Society of Intensive Care Medicine. Intensive Care Med. 2014, 40, 1795-1815. [CrossRef]

2. Labovitz, A.J.; Noble, V.E. Focused Cardiac Ultrasound in the Emergent Setting: A Consensus Statement of the American Society of Echocardiography and American College of Emergency Physicians. J. Am. Soc. Echocardiogr. 2010, 23, 1225-1230. [CrossRef] [PubMed]

3. Patel, A.R.; Patel, A.R. Cardiac Ultrasound in the Intensive Care Unit: A Review. Cureus 2019, 11, e4612. [CrossRef]

4. Britton, N.; Miller, M.A. Tele-Ultrasound in Resource-Limited Settings: A Systematic Review. Front. Public Health 2019, 7, 244. [CrossRef]

5. Ferioli, M.; Cisternino, C. Protecting healthcare workers from SARS-CoV-2 infection: Practical indications. Eur. Respir. Rev. 2020, 29, 155. [CrossRef]

6. Salerno, A.; Tupchong, K. Point-of-Care Teleultrasound: A Systematic Review. Telemed. J. E Health 2020, 26. [CrossRef]

7. Moher, D.; Liberati, A.; Tetzlaff, J.; Altman, D.G.; The PRISMA Group. Preferred Reporting Items for Systematic Reviews and Meta-Analyses: The PRISMA Statement. PLoS Med. 2009, 6, e1000097. [CrossRef]

8. Boniface, K.S.; Shokoohi, H. Tele-ultrasound and paramedics: Real-time remote physician guidance of the Focused Assessment wWith Sonography for Trauma examination. Am. J. Emerg. Med. 2011, 29, 477-481. [CrossRef] 
9. Russell, P.M.; Mallin, M. First "glass" education: Telementored cardiac ultrasonography using Google Glassa pilot study. Acad. Emerg. Med. 2014, 21, 1297-1299. [CrossRef]

10. Robertson, T.E.; Levine, A.R. Remote tele-mentored ultrasound for non-physician learners using FaceTime: A feasibility study in a low-income country. J. Crit. Care 2017, 40, 145-148. [CrossRef]

11. Ramsingh, D.; Ma, M. Feasibility Evaluation of Commercially Available Video Conferencing Devices to Technically Direct Untrained Nonmedical Personnel to Perform a Rapid Trauma Ultrasound Examination. Diagnostics 2019, 9, 188. [CrossRef] [PubMed]

12. Olivieri, P.P.; Verceles, A.C. A Pilot Study of Ultrasonography-Naïve Operators' Ability to Use Tele-Ultrasonography to Assess the Heart and Lung. J. Intensive Care Med. 2020, 35, 672-678. [CrossRef]

13. Afset, J.E.; Lunde, P. Accuracy of routine echocardiographic measurements made by an inexperienced examiner through tele-instruction. J. Telemed. Telecare 1996, 2, 148-154. [CrossRef]

14. Becker, C.; Fusaro, M. Tele-Ultrasound to Guide Management of a Patient with Circulatory Shock. Am. J. Med. 2017, 130, e205-e206. [CrossRef] [PubMed]

15. Otto, C.A.; Shemenski, R. Real-time tele-echocardiography: Diagnosis and management of a pericardial effusion secondary to pericarditis at an Antarctic research station. Telemed J. E Health 2012, 18, 521-524. [CrossRef]

16. Epstein, D.; Petersiel, N. Pocket-size point-of-care ultrasound in rural Uganda-A unique opportunity "to see", where no imaging facilities are available. Travel Med. Infect. Dis. 2018, 23, 87-93. [CrossRef] [PubMed]

17. Douglas, T.M.; Levine, A.R. Brief training increases nurses' comfort using tele-ultrasound: A feasibility study. Intensive Crit. Care Nurs. 2019, 51, 45-49. [CrossRef]

18. Levine, A.R.; Buchner, J.A. Ultrasound images transmitted via FaceTime are non-inferior to images on the ultrasound machine. J. Crit. Care 2016, 33, 51-55. [CrossRef]

19. Kim, C.; Hur, J. Can an Offsite Expert Remotely Evaluate the Visual Estimation of Ejection Fraction via a Social Network Video Call? J. Digit. Imaging 2017, 30, 718-725. [CrossRef]

20. Miyashita, T.; Takizawa, M. Telemedicine of the heart: Real-time telescreening of echocardiography using satellite telecommunication. Circ. J. 2003, 67, 562-564. [CrossRef]

21. Huffer, L.L.; Bauch, T.D. Feasibility of remote echocardiography with satellite transmission and real-time interpretation to support medical activities in the austere medical environment. J. Am. Soc. Echocardiogr. 2004, 17, 670-674. [CrossRef]

22. Jensen, S.H.; Weile, J. Remote real-time supervision via tele-ultrasound in focused cardiac ultrasound: A single-blinded cluster randomized controlled trial. Acta Anaesthesiol. Scand. 2019, 63, 403-409. [CrossRef]

23. Levine, A.R.; Robertson, T.E. Tele-Medicine and Point-of-Care Ultrasound: A New Paradigm for Resource-Constrained Settings. Chest 2016, 149, 1580-1581. [CrossRef]

24. Paulus, Y.M.; Thompson, N.P. Inexpensive, realtime tele-ultrasound using a commercial, web-based video streaming device. J. Telemed. Telecare 2012, 18, 85-188. [CrossRef]

25. Jajodia, A.; Ebner, L. Imaging in corona virus disease 2019 (COVID-19)-A Scoping review. Eur. J. Radiol. 2020, 7, 100237. [CrossRef]

26. Rubin, G.D.; Ryerson, C.J. The Role of Chest Imaging in Patient Management During the COVID-19 Pandemic: A Multinational Consensus Statement fFrom the Fleischner Society. Chest 2020, 158, 106-116. [CrossRef]

27. American College of Radiology. Available online: https://www.acr.org/Advocacy-and-Economics/ACR-PositionStatements/Recommendations-for-Chest-Radiography-and-CT-for-Suspected-COVID19-Infection (accessed on 1 August 2020).

28. Szekely, Y.; Lichter, Y. Spectrum of Cardiac Manifestation in COVID-19: A Systematic Echocardiographic Study. Circulation 2020, 142, 342-353. [CrossRef]

29. Soldati, G.; Smargiassi, A. Proposal for International Standardization of the Use of Lung Ultrasound for Patients With COVID-19: A Simple, Quantitative, Reproducible Method. J. Ultrasound Med. 2020, 39, 1413-1419. [CrossRef]

Publisher's Note: MDPI stays neutral with regard to jurisdictional claims in published maps and institutional affiliations.

(C) 2020 by the authors. Licensee MDPI, Basel, Switzerland. This article is an open access article distributed under the terms and conditions of the Creative Commons Attribution (CC BY) license (http://creativecommons.org/licenses/by/4.0/). 